\title{
AIDS and the Non-Life Insurance Market
}

\author{
by A. A. Cassidy*
}

I am neither an actuary, an economist, a sociologist nor a scientist - just a non-marine underwriter at Lloyd's, whose job it is to assess risks accurately enough to ensure that at the day of reckoning, premiums exceed claims. My margins are thin and expense ratios cause constant concern, so how can I, at the expense of myself and my Names, ignore AIDS - a fatal disease against which there is no vaccine and for which there is no cure - and none is in prospect for at least five years. Please accept that the views expressed in the paper are my own and do not necessarily reflect the thinking of Lloyd's or even other underwriters at Lloyd's.

It is quite understandable why the life assurers should have appreciated more quickly than non-life insurers the threat posed by AIDS. Being fatal and attacking particularly the age group 25-40, it undermines the adequacy of rates developed from current mortality tables to the extent they become no longer valid in that group where they are the most sensitive from a statistical point of view.

The threat is greatest perhaps in the United States, where the sufficiency of reserves posted by some of the younger companies, operating in a very competitive market, may with the emergence of AIDS, lead to questions being asked even as to their solvency.

The bold decision by Zurich Life in April when they doubled and even trebled some of their term assurance rates on males aged between 25 and 55, was a dramatic statement as to how far the old rates had been undermined; and no-one was surprised when others in the UK also increased their rates, or when Commercial Union brought out the first term assurance policy that specifically excluded death from AIDS. One suspects group schemes and permanent health insurance must soon suffer the same treatment.

Worldwide, many life assurance companies are also imposing supplementary questionnaires as a defence against future anti-selection, and in the UK alone, beginning to post a rumoured $£ 1000$ million in additional reserves against existing lives assured. So yes, the life market has recognised its AIDS related problems: but what of the non-life market?

\footnotetext{
* Lloyd's, London. Paper presented at the 15 th General Assembly of the Geneva Association, The Hague, June 13-14, 1988
} 
Some would claim that the non-life market, emboldened perhaps by the profits of recent years, is sitting with all the complacency of the US Pacific Fleet in Pearl Harbour during the first week of December, 1941. Warnings have been received, signals have been sent, but too many have been overlooked, discounted or ignored. But how real is the threat?

It might be as well here to outline those classes of non-life insurance which the subcommittee set up by the Non-Marine Association of Lloyd's in November, 1986 to research the possible impact of AIDS, originally identified as being exposed - and why. A similar Working Party was set up in April 1987 by the Association of British Insurers. However, although the two bodies work closely together, the findings expressed below owe more to the former than to the latter. In the certain knowledge no AIDS Exclusion Clauses were then in force, those classes of insurance identified as having possible exposure to AIDS claims were as follows: -

Medical; self-evidently, because sufferers will require treatment and hospitalisation before death.

Personal Accident; irrespective of whether policies cover death only or temporary or permanent disablement; this largely because of fears that, particularly in the United States, the act which caused the infection will be deemed an accident unless the insurer can prove the infection was passed deliberately.

Travel; not so much under the medical section, more under that section which covers the costs of repatriation, where the risk arises from the fear of conctracting AIDS from medical treatment provided in a country where AIDS is prevalent and medical hygiene unsatisfactory.

Motor; because of liability to a third party contracting AIDS following an accident, either as a result of him assisting an injured driver or passenger who is HIV positive, or sustaining injury which causes him to be transfused with infected blood.

Householders Comprehensive; under the liability section because a third party suffers injury on the premises and contracts AIDS, or because the householder, being himself HIV positive, infects, say, a live-in lover.

Medical Malpractice; arising from failure to diagnose; wrong diagnosis; failure to communicate knowledge to a spouse or, conversely, breaching patient confidentiality by communicating knowledge to a spouse; prescribing the wrong treatment.

Hospital Medical Malpractice; as above, plus a myriad of other potential risks associated with providing full time care; not least patients contracting AIDS from blood transfusions or doctors and nurses themselves infected.

Products Liability; arising from such diverse products as blood plasma, blood screening devices and drugs which, whilst claiming to cure or prolong life may, in some instances, do neither, or may cause unpredicted and unacceptable side-effects.

Errors and Omissions; being the professional liability arising from the failure to provide promised services by, inter alia, lawyers, architects, engineers, insurance agents. Of these, lawyers and insurance agents may prove to be the most exposed because of the likely highly-charged atmosphere in which AIDS related litigation will be conducted, and because of their close association with the insurance industry. 
Legal Expenses; defence costs incurred by employers contesting suits for discrimination, unfair or constructive dismissal; or by individuals defending or issuing AIDS related charges.

Employers Liability; arising from employees claiming negligence as a result of which they contracted AIDS at work, either through the nature of their work or from sexual contact with a colleague known by the employers, but not the employee, to have been an AIDS carrier; or from employees claiming discrimination, unfair or constructive dismissal because they had AIDS or even because they were HIV positive.

Before demonstrating that this exposure to AIDS claims is not fanciful but real to nonlife insurers, we must acknowledge how difficult it is to assess the vulnerability of individual classes of the non-life market to AIDS related claims. The problem is that the threat, in many classes, is as yet so abstract.

By "abstract" I mean that whilst in medical insurance, for instance, the financial impact of AIDS can begin to be measured, this is not so in most classes of liability insurance, where the vulnerability of insurers will depend so much on the attitude of society towards AIDS sufferers.

In this regard, four points are important: -

1. Perhaps because of the distressingly bleak prospects for AIDS sufferers, and its intimate association in the West with homosexuals and intravenous drug abusers, the very presence of the disease invokes abhorrence and dread.

2. Attitudes will be very different towards those identified as innocent rather than culpable sufferers.

3. As we see them, so shall we believe society will see us, should we ourselves become sufferers.

4. Education, or the lack of it, will play a significant role.

Thus, in non-life insurance terms, we have a disease which is not only life-threatening, disabling and expensive to treat, but also tailor made to bring out the worst in homo sapiens: - possessed of a little knowledge, he will be discriminatory, greedy and, on occasions, out for revenge.

The attitudes of societies across the world may well very almost to the extent that the languages they speak differ: and may I ask you to accept that, lacking both the time and the knowledge to cover a number of countries, I will tend to search for clues as to what those attitudes may prove to be, by looking at developments in the United States.

Hopefully, you will agree this is not an entirely illogical approach. Of the countries in the western world, the USA was the first to get hit hard by AIDS. Also I have enjoyed travelling and working in America and with Americans for more than twenty five years. Of us all, it seems to me to be the land where, on the one hand, you have a people who are the most generous, most free, most advanced in educating their young for the technology of tomorrow, and the most concerned for those less fortunate than themselves. On the other hand, there exists some evidence that in aspects of their lives, some of them are the most avaricious, the most determined to retain their personal rights and freedom at no matter what cost to others, the most parochial and short-sighted, and the most discriminatory 
people on earth. Since most of Lloyd's non-marine premium income is in dollars and it is sometimes useful to take extremes to make a general point, I will, with apologies to my American friends, take the USA as being a suitable case for treatment!

In general terms, is it not perhaps true that, except when at war, the attitudes of a society are likely to be influenced above all else by the following abstracts,

1. the nature of its people

2. the intent behind the legislation imposed upon it

3. the effectiveness of its legal system.

Each abstract interacts with the other, but the first is, in essence, the product of the history of the country concerned, for in that political, religious and military history will have been forged the aspirations of its people. And in so far as those aspirations have been attained, so will its people's levels of expectation have been raised or lowered.

Now, what is legislation if not a mix of what successive governments have felt it necessary to enact either to protect their people from themselves and each other, defend them against outsiders or, when politically expedient, give their people, or at least some of them, something they would otherwise not have had - invariably at the expense of others.

And what should the legal system be, if not the effective conduit by which the decisions of the legislature can be enforced without fear or favour?

So far, so good, but what if the country's legal system begins to crack so that its decisions are not always free of bias, and worse, what if the legislature itself appears to condone the partiality of its courts?

The end result is that the attitudes of that society will change, because as it receives what it will regard as a bonus made available by its own legal system, so its levels of expectation will increase; and the more its greater expectations are met, so will it become more avaricious. Then you are off on a vicious and dangerous circle whose circumference can only grow. Morality in general will decline, because morality is more governed by doing unto others what we would have them do unto us, than it is by grabbing what we can from whomever we can, regardless of who gets hurt or the merits of our case. Also, immorality appears to be rather more infectious than morality.

Again, forgive me for being simplistic about an extremely complex issue, but the relevance of the attitude that society adopts towards the AIDS issue is such it can not be ignored.

AIDS sufferers are going to be inclined to seek recourse in the courts; and the degree of their inclination will be determined by the level of discrimination they encounter, the level of encouragement they get from the legal fraternity, and the levels of sympathy and generosity they find in the decisions taken in the courts.

To look at the world for non-life insurers tomorrow, look at America today, and be warned. In the shape of the decisions taken and the size of the awards given in the courts, the mass of evidence that exists to prove the bias of the American legal system against the insurance industry is now so great as to cause concern to us all; not least because whilst we do not all have jury awards, contingent legal fees, joint and several liability and punitive damages, there are many signs that other legal systems in Europe are beginning to be influenced by the attitudes that pervade America. How can it be otherwise? As our 
societies become more affluent, they become more materialistic, therefore more litigious, and the courts and those that serve them will have no alternative but to respond to the changes in the attitudes of the people, because the governments will see to it that they do. UK.

My fear is that the seeds of just that sort of legal climate have already been sown in the

To demonstrate our vulnerability as insurers in the UK to the decline in general morality, we have to look no further than Mr Haswell, our insurance ombudsman, installed in 1981 to see that insurers played fair by their insureds, especially members of the public neither versed in business nor insurance. In April this year, $\mathrm{Mr}$ Haswell bluntly gave out the facts. Of the 7,500 people who asked the ombudsman for help last year, he found only 304 of the 1,449 investigated had shown the claimant had a fair case. Mr Haswell went on to advocate that insurers should make a habit of investigating a percentage of all claims and not to hesitate prosecuting those found to have made fraudulent claims.

At the same time, none of us will have failed to notice the escalation in awards in the UK during the past five years. Today, awards of $£ 500,000$ are not unusual where five years ago, half that sum would have been awarded.

Is the climate any better elsewhere in Europe? I doubt it.

So where are we? We are an industry having to cope with a problem as immeasurable and emotive as AIDS; an issue exposed to a number of influences outside our control, such as a clientele drawn from societies with attitudes likely to make them increasingly litigious and more inclined to claim against insurers, legal systems under pressure, governments under duress because they have in AIDS a problem they cannot resolve, and, lest we forget, a medical profession who it is all too evident have yet to identify, in the difficult circumstances surrounding AIDS patients, what is right or wrong. For doctors, what are the duties of confidentiality? Without clear guidance from the British Medical Association and similar bodies, should they act as priests or informers?

Meanwhile, relevant case histories mount in number in the courts around the world, and it may well be that the decisions taken by these judges and juries will determine our ability to provide to our insureds the products they need at a price they can afford.

Turning again to America for clues as to where we may be heading, surely many recognise by now that in America the liability insurance market is nothing less than the chain mail that separates the body of the insured from the invasive legal thrusts propelled at him by those to whom he has provided a product or a service and has, in some regard, disappointed; be that insured a manufacturer, medical practitioner or the owner of a day-care centre.

May we now briefly examine each of the classes originally identified as being exposed and see what has happened in the intervening period to show whether our concerns are valid or invalid.

Medical. No surprises here. All governments have accepted that the cost of providing health care to AIDS sufferers is going to be so massive that resources will need to be diverted. For instance, it has been estimated in the UK that the cost of providing health care to the expected 3000 new cases which will be diagnosed during 1988 will absorb what would otherwise have been available to provide acute hospital treatment to more than 120,000 non-AIDS patients. 
The average total cost of providing health care to an AIDS sufferer in the USA is thought to be some $\$ 58,000$. Although down from the figure of $\$ 140,000$ used two years ago, it is an average always subject to the possible double impact of new specialist drugs such as AZT: - higher costs and treatment over a longer period. With a suspected 2 million Americans already infected, the total cost of providing health care will be staggering.

It is naive to believe that some medical costs will not be shifted by one means or another on to the insurance industry, but the inflation in such costs will be measurable. Nevertheless, this has not stopped the British United Provident Association from excluding cover for AIDS on new members under their medical schemes for the first five years.

On a global basis, particularly in those countries with inadequate medical facilities and levels of HIV infection approaching $20 \%$ in broad sections of their populations, as is the case of some central and western African countries, it will be a brave insurer who gives medical cover without an AIDS Exclusion Clause.

The admissability of testing, and asking questions as to lifestyle and sexual orientation, will vary year by year, country by country and in the United States, state by state. With careful underwriting the problem can be contained.

Personal Accident. In the United States, evidence suggests a number of companies, particularly when Californians are involved, have settled claims for AIDS deaths occurring as the result of transfusions, regardless of whether the date of death was outside the time limitation imposed in the policy. In the legal climate prevailing, they probably believed it wise to settle quietly, not least because of an American legal quirk known as the Process of Nature Rule. Under this Rule insurers may in some states find themselves liable for death occurring many years after an accident. It is no more than a convenient legal tool, which contrives to make "immediate" something that happened years previously.

To my mind, to view infection by transfusion an accident, is extremely dangerous. It threatens to open Pandora's box, releasing as legitimate all sorts of claims arising from other kinds of medical treatment and, most probably, claims following death or disablement from AIDS however the infection was passed. At least in one state, Maryland, reason is seen to have prevailed when, in Cheney v Bell National Life Ins. Co. it was held that infection from a transfusion was not an accident.

Another concern to non-life insurers must be the growing tendency of law courts on both sides of the Atlantic to admit emotional trauma as bodily injury. Some have speculated that a spouse who goes into emotional shock on hearing, for instance, his or her spouse is HIV positive, may succeed in establishing injury within the normal terms of an accident policy. The implications of this in the context of AIDS could be serious.

As an underwriter providing death or disablement cover under personal accident and health insurance, I have felt it necessary, because premiums are so low when compared to the sums insured, to insert an Aids Exclusion Clause couched in clear and unambiguous terms; not least since new mutants and variations of the virus continue to emerge. My syndicate has tried to do just that and the exclusion reads:

"This insurance does not cover death or disablememt directly or indirectly arising out of or consequent upon or contributed to by: 
... Acquired Immune Deficiency Syndrome (AIDS) or Aids Related Complex (ARC), howsoever this syndrome has been acquired or may be named."

No doubt, we will be prepared to consider its deletion on the payment of an additional premium or satisfactory answers being given on a supplementary questionnaire.

Travel Insurance. Today, travellers to South America and sub-Saharan areas of Africa stand a 100 times greater risk of contracting AIDS as a result of medical treatment than in Britain. Syringes may not be adequately sterilised in some third-world countries, and elsewhere, such as in Brazil, donors are paid for donating blood and screening techniques may not always be entirely thorough. For all these reasons, and because premiums are small and the costs of emergency repatriation high, insurers are beginning to employ exclusionary language to protect themselves from what have come to be known as "Fear of AIDS" claims.

On the subject of "Fear of AIDS" claims, it is noteworthy that extortioners have been quick to add the fear of AIDS to their arsenal of threats. Earlier this year in Sidney, Australia, a 15 year old boy was kidnapped and his parents threatened that unless a ransom of A $\$ 500,000$ was paid, the child would be infected with the AIDS virus. The same strategy was employed in Brazil in May by a man who said he had AIDS. He demanded $£ 8$ million in ransom and threatened that, if not paid, he would inject 13 hostages with his blood. He was shot.

Similarly, in the High Court, Belfast, a man and his several accomplices were convicted in April for attempting to extort $\$ 350,000$ from a London branch of Marks and Spencer, using the threat that unless such money was paid, food products would be contaminated with the blood of an AIDS victim.

Motor. At the end of 1986 in Perth, Australia, a young man who contracted AIDS following a massive blood transfusion as the result of a motor accident in 1983, was awarded the equivalent of $£ 332,000$ in damages against the driver of the car responsible and his insurers. In making the award, the Judge took into account the contraction of AIDS.

In February, 1988, the first legal action in Britain was brought by a single woman in her 20 's against the driver of a car which knocked her down. As a result, she required a blood transfusion from which she became infected with the HIV virus. If successful, the driver's insurers will have to pay compensation not only for the serious injuries sustained, but also her infection.

Householders Comprehensive. In the USA and Canada, outraged spouses and lovers are increasingly suing their partners after contracting genital herpes. The present surge of litigation is largely based on the claim that one partner did not inform the other about his or her infection. This, the suit often charges, constitutes negligence. In a successful case brought in March, 1987, one such settlement was finally agreed in the sum of $\$ 119,052$, to be paid by the insurer after the plaintiff's attorney established that the defendant was covered by a homeowners policy, making it possible to collect on a judgement.

In a pending case in Minnesota, a suit has been filed against the defendant sexual partner for failure to inform, notify or warn the female plaintiff that he suffered from Aids Related Complex or of his past exposure to HIV, alleging severe and permanent injuries, as well as loss of future earnings, and medical expenses. 
Whilst it has been pointed out that litigants may have more difficulty in proving their case when AIDS is involved, because of the time lag between exposure to the virus and development of the disease, the insurance industry has begun to change "homeowners" policies to exclude claims arising from communicable disease.

Medical Malpractice. In the United States, a number of cases are in the pipeline involving breach of confidentiality and suits have been filed against three Pennsylvanian physicians over alleged secret AIDS testing. The plaintiffs claim that, by testing them without their knowledge, the physicians invaded their privacy and caused them emotional distress. In Ramos v Harvard Community Health Plan, Inc., the plaintiff sued her physician for malpractice for failing to diagnose her AIDS. The plaintiff was originally diagnosed in 1985 as having asthma and imaginary ailments. She sought to recover her medical costs as well as damages for pain and suffering. The Boston doctor was found negligent in this treatment and diagnosis and the plaintiff was awarded $\$ 500,000$. Her two sons were awarded $\$ 125,000$ each.

Perhaps because premiums are high and AIDS is but one of the very many sources of the malpractice claims which are brought annually, insurers seem relaxed and believe they can adjust their rates and forms as they become able to judge where they are most exposed.

Hospital Medical Malpractice. In a recent article from the Journal of the American Medical Association, it was reported that only $34 \%$ of the 189 hospitals surveyed, obtained prior consent before testing for the AIDS virus. In the wake of the suits filed against the Pennsylvanian physicians, it is now realised that if the plaintiffs in that case succeed, then professional liability exposure is considerable. In John and Jane Smith v American National Red Cross, a Maryland man who contracted the HTLV-III virus following a blood transfusion, has filed a $\$ 25$ million suit for negligence.

In Polikoff v University of California, a 63 year old San Diego woman is suing the hospital for $\$ 1$ million in compensatory damages after she became infected through sexual relations with her husband, who had contracted and died from AIDS following a blood transfusion. However, one can record here that the situation in US Courts became so alarming that 45 states have now passed special legislation to deal with the problem of the transfusion of contaminated blood products - usually by declaring the process involves the rendering of a service, not the sale of blood products.

In the UK, two brothers, both haemophiliacs, became the first to sue the National Health Service for allegedly treating them with blood clotting agents contaminated with the AIDS virus. It is believed solicitors are already preparing about a hundred claims for negligence against the health authorities.

The whole subject of confidentiality and the breach of privacy is a very live issue throughout the USA and Europe.

Although insurance rates are also high for Hospital Malpractice cover, it seems inevitable in the face of all the conflicting pressures that confront hospital management, that insurers will soon require questions to be answered concerning the hospital's policy of testing staff for the HIV virus, establishing how and if they isolate those who are found to be HIV positive, and the numbers known to be infected. Also, whether or not the hospitals maintain specialist AIDS units. 
Although out of context, it is worth mentioning here that those who administer prisons face much of the same problems as hospital administrators, and there is considerable legal activity in the USA on the AIDS front from lawyers acting on behalf of inmates.

Products Liability. Although, in what is considered a landmark ruling in the United States, an unnamed woman has been permitted to sue Miles Laboratories for supplying allegedly contaminated blood products from which she contracted AIDS, there has to date been little success for plaintiffs.

However, around the world, lawyers representing haemophiliacs will be attempting to recover damages from manufacturers of blood products.

From an insurer's point of view, with the introduction of screening, it might appear the problem belongs to the past. The concern must be that, as happened recently, a new strain of the virus is found which is not identified by screening measures in force at the time.

Insurers will also view with great caution new drugs being brought to the market which will not have been made subject to all the stringent tests normally conducted before a new product is released; this because of the desperate nature of the search for a drug that will either retard, cure or prevent AIDS.

Errors and Omissions. Being another high risk, highly rated class of insurance where insurers are using forms which, more often than not, only cover claims made during the policy period, there seems little cause yet to resort to exclusions or increased rating. It will be a case of wait and see.

In one case in the United States, (Campanella v Hurwitz), the estate of a patient is suing his dentist for compensatory damages, for refusing to treat him, referring him instead to a hospital. He has since died.

Legal Expenses. I can find no instances where insurers have been involved in AIDS claims and it seems unlikely either rating or forms will change until there are definite signs of activity.

In the meantime, insurers can do no more than always to bear in mind that the risk is there and to prepare themselves ahead of the event.

Employers Liability. This class of insurance is a potential minefield and perhaps more than any other class will be subject to the whims of the attitudes of society. Fear, stigma, greed, discrimination, and revenge will be amongst the forces at play and employers will all too often find themselves in a "cannot win" situation.

Some employers will be more exposed than others, such as those dealing directly with the public or employing hospital or laboratory staff, kitchen staff, or prison staff. Employers in dealing with employees with AIDS will have to learn how to be seen by other employees as protecting them against a perceived risk, while at the same time not to be seen as discriminating against an employee who at law is likely to have all the advantages of a person classified as "handicapped".

The number of suits being brought against employers is already substantial and can only get worse. Employers worldwide will be in the front line, for what they or their employees have done and for what they have not done. 
Employers are going to need cover to the extent that they will be prepared to pay more for it. Insurers should provide that cover at reasonable rates, but in the face of the unknown, only time will tell whether the rates charged were inadequate, reasonable, or iniquitous.

In conclusion, what do we have but a killer disease for which there is no imminent cure, a disease which, until a cure is found, will tend to make social lepers of all who suffer from it, regardless of how they became infected; a disease which each of us from our own individual standpoint will view as being either unfair or unclean.

As non-life insurers, the one great advantage we enjoy over our colleagues in the life market is that our policies tend to be annually renewable, and the benefits given short-term.

Provided therefore that we remain alert and monitor every movement of a new but recognised adversary and its influence on legislators, the courts and, all important, the attitudes of our respective societies, then we shall be well placed to close our defences in the face of any threatened and endangering breakthrough; regardless as to whether that threat stems from covert anti-selection, the creation of legal loopholes or the emergence of new strains of the deadly syndrome.

In the face of interested consumer associations and minority groups who have begun to lobby government departments on an international scale, no one has so far been able to charge the non-life market with panicking in the face of AIDS.

We are doing our homework quietly, and will exercise sensible caution where it becomes evidently necessary we must act to protect our members, shareholders and, most importantly, the long term benefit of those whom we serve - our insureds. 